\title{
Naród, gender, popkultura. Nacjonalistyczne konstrukcje płci i seksualności w popkulturowej odsłonie
}

\section{KEYWORDS}

nationalistic discourse, gender, sexuality, pop culture

\begin{abstract}
Zamojska Eva, Naród, gender, popkultura. Nacjonalistyczne konstrukcje płci i seksualności w popkulturowej odsłonie [Nation, gender, pop culture. Nationalistic constructs of gender and sexuality in pop cultural attire]. Kultura - Społeczeństwo - Edukacja nr 2(12) 2017, Poznań 2017, pp. 361-378, Adam Mickiewicz University Press. ISSN 2300-0422. DOI 10.14746/kse.2017.12.18.
\end{abstract}

The paper is a short theoretical summary of relationships between the notions of nation, gender and sexuality in a nationalistic discourse. It is also an attempt at applying this knowledge for analyzing selected artifacts of pop culture. In the first part of the paper, theoretical and research findings on the constructs of gender and sexuality in a nationalistic discourse are presented. In the second part these findings are used for a discursive analysis of gender and sexuality constructs in selected songs / stage acts presented at the Eurovision Song Contest 2014 and a pastiche cover version of one of them.

* Będę w tym tekście używała zarówno pojęcia „gender”, jak i „płeć” z powodu niejednolitej praktyki w ich stosowaniu w polskich tekstach akademickich, choć uważam je za określenia bliskoznaczne. Radykalne rozróżnienie na gender i płeć (po polsku także rodzaj, płeć kulturowa, płeć społeczna versus płeć biologiczna) miało znaczenie u początków kształtowania się teorii feministycznej. Współcześnie, kiedy w naukach społecznych rozważana jest płeć, przyjmuje się założenie, iż odnosi się ona nie do biologicznej różnicy między ciałami kobiet i mężczyzn, lecz do konsekwencji tego rozróżniania w życiu społecznym. Użycie pojęcia gender w tej sytuacji najczęściej sygnalizuje akces do określonej teoretycznej i metodologicznej opcji - konstruktywizmu społecznego. 
Jako kobieta nie mam kraju, jako kobieta nie chcę mieć kraju, moim krajem jako kobiety jest cały świat Virginia Woolf

\section{Wstęp}

Wielu badaczy zwraca uwagę na istotność popkultury dla procesów tożsamościowych młodzieży i postuluje, by uwzględnić ją wśród filarów procesów kształtowania tożsamości młodych ludzi - w edukacji i socjalizacji (Melosik, 2013; Jakubowski, 2007; 2014;). Niesione przez nią treści można więc rozważać jako element dyskursu edukacyjnego.

Pojęcie „dyskurs” funkcjonuje w różnych znaczeniach. Tutaj odwołuję się do dwóch z nich. Kiedy posługuję się pojęciem „dyskurs edukacyjny”, mam na myśli dyskurs jako „zespół poglądów wyrażanych w danej dziedzinie czy dyscyplinie wiedzy (...) lub zespół poglądów głoszonych w ramach dyskusji związanych $\mathrm{z}$ danymi zagadnieniami" (Stasiuk, 2003: 33). Kiedy piszę o dyskursie nacjonalistycznym, przyjmuję, że dyskurs można rozumieć jako zespół „propagowania koncepcji i idei" (Van Dijk, 2001: 10). Jednocześnie chcę podkreślić, że samo używanie pojęcia "dyskurs” wskazuje na przyjęcie założeń konstruktywizmu społecznego, czyli na przekonanie, iż komunikacja społeczna, nadawanie i interpretacja znaczeń, konstruuje rzeczywistość społeczną. Dyskurs w rozumieniu „propagowania koncepcji i idei" ma w podtekście dążenie do hegemonii, do zawładnięcia przestrzenią symboliczną, ale też jest podatny na dekonstrukcję (Mouffe, 2008; 2015; Jaskułowski, 2012: 54).

Podstawową strategią badawczą w badaniu dyskursu jest wydobycie i interpretacja znaczeń, które przypisywane są pojęciom odnoszonym do rzeczywistości przez konkretne podmioty społeczne, w określonych sytuacjach historycznych, określonych kontekstach, często także w celu ustanowienia hegemonii. Znaczenie jest tworzone $\mathrm{w}$ trakcie komunikacji społecznej, ale może też być zniesione, obalone, zastąpione innym, alternatywnym znaczeniem. Nie oznacza to jednak, że mamy do czynienia $\mathrm{z}$ absolutnym indywidualizmem (solipsyzmem) czy z woluntaryzmem w ich ustalaniu. Chodzi tu raczej o uwypuklenie intersubiektywnej, komunikacyjnej natury rzeczywistości, w której wszyscy żyjemy. Dyskurs edukacyjny to zespół idei funkcjonujących w odniesieniu do rzeczywistości edukacyjnej formalnej i nieformalnej, jest on wewnętrznie zróżnicowany, uwikłany w historyczne, ideologiczne i polityczne konteksty. Dyskurs nacjonalistyczny definiuję jako jeden ze sposobów ujmowania rzeczywistości społecznej, w której kategorią 
centralną jest specyficznie konstruowana wspólnota zwana narodem. Zawiera on również treść afektywną (emocjonalną), wyrażającą się w przekonaniu, iż przygodna, z punktu widzenia historii długiego trwania, forma organizacji społeczeństwa - naród - to forma jedyna i najlepsza.

Pozytywne uczucia młodego pokolenia Polaków i Polek względem narodu utrzymują się na wysokim poziomie od lat i nie dają się w prosty sposób powiązać z bieżącymi wydarzeniami politycznymi, które mogłyby być interpretowane jako zagrożenie narodowego bytu. Już w 2005 roku Krzysztof Koseła, podsumowując badania nad postawami patriotycznymi młodzieży, pisał:

Gorący patriotyzm młodych Polaków ma tę ciekawą cechę, że trudno pokazać, kto go żywi i roznieca. Słaby związek z cechami rodziny, szkoły, środowisk rówieśniczych każe twierdzić, że młodzi Polacy narodowy zapał czerpią z powietrza, czyli zewsząd; że są zanurzeni w przestrzeni, która podsuwa im narodowe treści. (...) Nie widać żadnej luki pokoleniowej ani gleby dla konfliktu pokoleń. (...) Dla osób nieletnich przynależność narodowa jest cechą oczywistą, nieproblematyczną. (...) Większa osobista doniosłość identyfikacji narodowych od jakichkolwiek innych ma konsekwencje w postaci gotowości świadczenia na rzecz narodu, nie zaś wspólnoty regionalnej lub europejskiej. (Koseła, 2005)

Z długoterminowej perspektywy wydaje się dziwne że w dobie globalizacji, tworzenia się ponadnarodowych wspólnot i instytucji taką żywotnością wykazują się podziały narodowe i reprodukcja narodowych tożsamości. W istocie, wbrew optymistycznym postmodernistycznym tezom z lat 90. XX wieku o końcu historii, płynnej nowoczesności, nomadycznej strukturze tożsamości współczesnych ludzi, stopniowym zanikaniu państwa narodowego, procesy narodotwórcze nie zostały osłabione (przykładem np. Szkocja, Katalonia, Kurdystan) i podziały narodowe są w rozkwicie. Być może przyczyny tego stanu rzeczy tkwią między innymi w tym, że takie zjawisko jak popkultura, która kanonicznie opisywana była jako idąca w poprzek a nawet przeciw narodowym identyfikacjom (Melosik, 2013), w swoich lokalnych przejawach nie jest wolna od treści nacjonalistycznych.

Przedmiotem artykułu są konstrukcje płci i seksualności w dyskursie nacjonalistycznym i ich przejawy w popkulturze. Dyskurs nacjonalistyczny w specyficzny - nierównościowy - sposób konstruuje płeć i seksualność. To stanowi wyzwanie dla ruchów emancypacyjnych kobiet i osób LGBTQ, ponieważ stoi w sprzeczności $\mathrm{z}$ dążeniem do przełamania heteronormatywności kulturowej, które stanowi jeden z warunków ustanowienia bardziej sprawiedliwego społecznego porządku płci.

W pierwszej części artykułu przedstawiam ustalenia teoretyczne i badawcze dotyczące konstrukcji płci i seksualności w dyskursie nacjonalistycznym, w drugiej części zajmuję się wybranymi artefaktami popkultury, wykorzystując ustale- 
nia teoretyczne do dyskursywnej analizy konstrukcji wspólnoty, płci i seksualności w nich zawartych. W podsumowaniu próbuję zinterpretować analityczne rozpoznania w kontekście dominujących przekazów socjalizacyjnych i zarazem, jak sądzę, istotnych cech dyskursu edukacyjnego w Polsce po 1989 roku.

\section{Konstrukcja płci i seksualności w dyskursie nacjonalistycznym}

Problem związków narodu i płci można zaliczyć do nurtu tak zwanej intersekcjonalności, który pojawił się w ramach badań nad płcią stosunkowo późno. W czasach powstawania teorii i badań spod znaku women's studies i gender studies określano się wobec, jak zakładano, uniwersalnie istniejącego systemu opresji kobiet (patriarchat) i operowano ogólnymi kategoriami „kobieta”, „mężczyzna”, badając uniwersalne mechanizmy różnicy płci. W późniejszej fazie rozwoju teorii i badań nad płcią przekształceniom ulegało samo rozumienie płci oraz pojawiły się bardziej wyrafinowane prace badające zależności między relacjami płci i szeregiem innych czynników, takich jak klasa, rasa i między innymi etniczność. Ogólnie rzecz biorąc, płeć nie jest już postrzegana jako cecha jednostki, jej tożsamości (w zależności od założeń teoretycznych bywa uważana za cechę przypisaną bądź zależną od norm kulturowych), lecz jako jedna ze struktur społecznych, która „ucieleśnia się" jako struktura nierówności w różnych obszarach życia społecznego. „Płeć to struktura relacji społecznych, która skupia się na arenie rozrodczości, oraz zespół praktyk, które przenoszą różnice między ciałami w zakresie budowy układu rozrodczego na sferę procesów społecznych" (Connell, 2013: 31).W realnym życiu różne struktury nierówności wzajemnie się splatają i wzmacniają, i choć „istnieje wiele powodów, dla których płeć należy traktować jako odrębną strukturę (...), chcąc w pełni zrozumieć ludzkie życie, musimy pamiętać, że relacje płci zawsze zachodzą w określonym kontekście i wchodzą w interakcje z innymi elementami dynamiki życia społecznego" (Connell, 2013: 150). Takim elementem może być etniczność lub przynależność narodowa. „Wzajemne zależności między relacjami płci, etnicznością i nowoczesnym nacjonalizmem stały się ważnym tematem książki Niry Yuval-Davis Gender and Nation (1997). Znaczenie tej problematyki rośnie, odkąd globalizacja znalazła się w centrum uwagi polityków i opinii publicznej" (Connell, 2013: 81-82).

Historiografia akademicka, tradycyjnie podejmująca problematykę narodu, rzadko uwzględniała kategorię czy perspektywę gender w swoich badaniach. Wytłumaczeniem tego faktu może być, jak podaje Monika Bobako, rewolucyjny czy 
„rewizjonistyczny” potencjał kategorii gender dla całości narracji historycznych, który wynika z uwikłania jej w epistemologię konstruktywistyczną.

\begin{abstract}
Aplikacja kategorii gender do historii ma na celu reinterpretację utrwalonych w naukowej historiografii narracji historycznych. W nieunikniony sposób owe reinterpretacje pociągają za sobą odsłanianie implicite przyjmowanych hierarchii wartości oraz związanych z nimi systemów dominacji, które wbudowane są w kulturę europejską oraz poszczególne tradycje narodowe. $\mathrm{Z}$ definicji zatem historia uwzględniająca perspektywę gender ma charakter „rewizjonistyczny”. (Bobako, 2005: 264-265)
\end{abstract}

Tak więc badaniem tego, w jaki sposób naród - a ściślej rzecz biorąc, dyskurs nacjonalistyczny - konstruuje porządek płci, kobiecość, męskość i w jaki sposób przyczynia się do kształtowania systemu nierówności płci, zajmują się głównie ci badacze i badaczki, przedstawiciele/ki różnych dyscyplin naukowych, dla których kategoria płci jest pierwszoplanowa (por. Acker, 2009; Scott Wallach, 2011; Anthias, Yuval-Davis, 2009; Janion, 2006; Graff, 2008; Mrozik, 2012; Grzebalska, 2013).

Dyskurs nacjonalistyczny rozumiem jako sposób ujmowania w mowie (języku) wszystkiego, co związane jest z pojęciem naród, tożsamością narodową, ideą narodu itp. Przymiotnik „nacjonalistyczny” nie ma tutaj żadnych wartościujących konotacji, odnosi się do jednej z głównych teorii politycznych wczesnej nowoczesności, powstałych w XIX wieku. Dyskurs nacjonalistyczny nie jest tożsamy $\mathrm{z}$ nacjonalizmem, nazizmem lub faszyzmem, choć wszystkie one są swego rodzaju jego skrajnymi przejawami. Obejmuje on również umiarkowaną postawę aprobaty wobec własnego narodu - patriotyzm. Agnieszka Mrozik określa nacjonalizm jako „dyskurs definiujący wspólnotę, która określa samą siebie jako naród” (Mrozik, 2012: 112). Podobnie jak inne projekty wczesnej fazy nowoczesności, takie jak liberalizm czy socjalizm, również nacjonalizm postuluje (obiecuje) emancypację - wyzwolenie. Jednak emancypacja ta nie dotyczy jednostki - obywatela (tak jak w koncepcjach liberalnych), czy podporządkowanej klasy społecznej (socjalizm typu marksowskiego), lecz specyficznie konstruowanej wspólnoty - narodu (Walzer 1999; Szacki, 2002). Według klasyków badań dyskursu nacjonalistycznego (Anderson, 1997; Gellner, 1991; Hobsbawn, 2010) pojęcie „naród” to abstrakcyjna „wspólnota wyobrażona”, która w początkowym okresie nowoczesności zastąpiła wspólnoty oparte na bliskościowych więziach społecznych, charakterystycznych dla społeczeństwa feudalnego. Narodowa wspólnota pełniła podobne funkcje jak wspólnoty rodowe, klanowe, wiejskie itp. - łączyła swoich członków więziami emocjonalnymi i była platformą dla społecznych identyfikacji, jednocześnie jednak idea narodowa wspierała procesy modernizacyjne - industrializację, ur- 
banizację i powszechne szkolnictwo. Z drugiej strony, w XX wieku pokłosiem nacjonalizmu/dyskursu nacjonalistycznego były dwie wojny światowe i Zagłada europejskich Żydów, toteż nawet w swojej umiarkowanej wersji - patriotyzmu jest to idea kłopotliwa. Współcześnie dynamiczne zjawisko globalnych migracji i powstawanie ponadnarodowych politycznych wspólnot, takich jak UE, stawiają pod znakiem zapytania nie tylko przydatność polityczną tej idei, ale odsłaniają także jej anachroniczność i kontrowersyjność w wielu różnych aspektach, między innymi w aspekcie porządku płci, który wbudowany jest w jej założenia.

Dyskurs nacjonalistyczny cechuje się uprzywilejowaniem wspólnoty względem jednostki. W konsekwencji prawa i zobowiązania poszczególnych osób istnieją tylko jako pochodne praw i zobowiązań wobec wspólnoty (Zamojska, 2010: 21-27). W skrajnych wersjach naród pojmowany jest analogicznie do organizmu biologicznego i każdy przejaw zachowania oraz myślenia jednostki oceniany jest przez wzgląd na ich funkcjonalność względem wspólnoty narodowej. Jeśli indywidualne zachowanie i myślenie nie są zgodne z interesem narodu, określane są jako zdrada narodu. Dyskurs nacjonalistyczny konstruuje naród jednocześnie jako wspólnotę naturalną i kulturową (Zamojska, 2010: 40-53). Te niewspółmierne perspektywy tylko z pozoru są nie do pogodzenia. Zazwyczaj nie są formułowane explicite, koegzystują w dyskursie in potentia. Spójność narodu uzasadniana jest przez wskazanie na wspólne cechy kulturowe i/lub biologiczne. W zależności od okoliczności do głosu dochodzi jedno lub drugie. J.G. Herder - jeden z ojców założycieli dyskursu nacjonalistycznego, jego kulturalistycznej wersji - widział naród jako wspólnotę połączoną atrybutami kulturowymi (wspólny język, religia, obyczaje), lecz w popularnych wyobrażeniach naród funkcjonuje analogicznie do rodziny, klanu - czyli grup związanych pokrewieństwem. Stąd między innymi romantyczne, legendarne mity o "praojcach” - założycielach narodu (Lech, Czech, Rus itp.). Do niedawna też w wielu europejskich systemach prawnych istniała reguła określania obywatelstwa/przynależności do narodu oparta na założeniu pokrewieństwa, tak zwane prawo krwi - ius sanguinis, na podstawie którego, w przeciwieństwie do innej reguły - prawa ziemi - ius soli, obywatelem/obywatelką państwa (narodowego) stawał/a się ten/ta, którego/której rodzice (a przynajmniej jeden z rodziców) byli obywatelami danego państwa/członkami danego narodu.

Naród w dyskursie nacjonalistycznym ma cechę wyjątkowości, która wspierana jest poprzez konstruowanie dumy narodowej, opartej między innymi na porównywaniu się z innymi narodami - w dziedzinie polityki, sportu, nauki, kultury itp. W badaniach psychologów społecznych udowodniono, że budowanie tożsamości społecznej w opozycji do grup innych, obcych, jest najskuteczniejszym sposobem wzmacniania więzi w obrębie grupy własnej i polega na tym, że „swoim” 
przypisujemy cechy pozytywne, a obcym negatywne (C.N. Macrae, Ch. Stangor, M. Hewston, 1999: 53). Konsekwencją takiej konstrukcji wspólnoty własnej jest etnocentryzm, ale także europocentryzm i orientalizm w znaczeniu, jakie temu pojęciu nadaje Edward Said (2005.), którym towarzyszą nieuchronnie postawy paternalizmu lub wyższości wobec innych.

Założenia wpisane w tak ujmowany naród są także podstawą specyficznych konstrukcji płci i seksualności. Dyskurs nacjonalistyczny zwykle „zamazuje” wszelkie różnice wewnątrz narodowego „my”. W kontekście rywalizacji z innymi wszelkie podziały wewnętrzne - społeczne, klasowe, regionalne, ekonomiczne, a także płciowe - schodzą na dalszy plan. Nie znaczy to jednak, że mężczyźni i kobiety w dyskursie nacjonalistycznym są sobie równi. Przy bliższym spojrzeniu okazuje się, że dyskurs nacjonalistyczny przydziela mężczyznom i kobietom różne role i zadania w celu podtrzymania trwania i funkcjonowania narodowej wspólnoty. Mężczyznom przypada głównie ochrona terytorium i ochrona tego, co się z terytorium wiąże, kobietom przede wszystkim rola reprodukcyjna - w znaczeniu biologicznym i symbolicznym, co skutkuje poddawaniem ich ciał i seksualności nieustającej kontroli.

Badaczki podkreślają, że słowem kluczowym (...) jest „reprodukcja” - nie tylko biologiczna, ale również symboliczna. Jej znakiem, terytorium, a jednocześnie granicą jest kobiece ciało. Wydając na świat potomstwo, kobiety pomnażają „zasoby ludzkie” danej społeczności, a więc decydują o sile bądź słabości narodu. (...) Opiekując się dziećmi, dbają o wychowanie ich w poszanowaniu wartości istotnych dla wspólnoty. W okresach wojny i niewoli funkcjonują z kolei jako figura, symbol narodowej tragedii i cierpienia, dopuszczone zaś do działań zbrojnych pełnią rolę służebną, opiekuńczą względem walczących/rannych/umierających mężczyzn. W dyskursie narodowym/nacjonalistycznym ciało kobiet naznaczone jest więc "piętnem reprezentacji”, a na niej samej - jako „symbolicznej okazicielce honoru wspólnoty” - spoczywa obowiązek „dźwigania ciężaru owej reprezentacji”. W związku z tym ciało kobiety (jej płodność, ale także seksualność) znajduje się pod ścisłą kontrolą wspólnoty etnicznej/narodowej, co czyni kobietę zakładniczką własnej społeczności. (Mrozik, 2012: 111-112)

Natomiast seksualność mężczyzn nie jest kontrolowana lub ograniczana. Ciało męskie nie jest bowiem obciążone narodową symboliką. Jedynym wymogiem co do męskiej seksualności w dyskursie nacjonalistycznym jest jej heteroseksualność, co ma oczywiście związek z jej reprodukcyjnym potencjałem.

Seksualność cudzoziemskich kobiet i mężczyzn w porównaniu z seksualnością „naszych” mężczyzn i kobiet jest zawsze rozważana jako gorsza i zwykle konstruowana jako niezgodna $\mathrm{z}$ "naszymi” normami, czyli dewiacyjna - oceniana jest jako zbyt wybujała albo jej walor reprodukcyjny jest podawany w wątpliwość przez nadanie etykietki homoseksualności. Seksualność cudzoziemek często trak- 
towana jest w oderwaniu od ich funkcji reprodukcyjnych, co skutkuje skrajnie przedmiotowym traktowaniem „obcych” kobiet jako wyłącznie obiektów seksualnych, zwłaszcza w czasie wojen i konfliktów zbrojnych (np. gwałty na niemieckich kobietach dokonywane przez żołnierzy Armii Czerwonej w czasie II wojny światowej, gwałty na kobietach w czasie konfliktu w byłej Jugosławii). W skrajnych przypadkach stosuje się eugeniczne praktyki w celu obniżenia lub eliminacji ich reprodukcyjnego potencjału (np. sterylizacja Romek w byłej Czechosłowacji (Zamojski, 2009) lub rdzennych mieszkanek Ameryki w Stanach Zjednoczonych ${ }^{1}$ ). Często kobietom pochodzącym z grup uważanych za „mniej cywilizowane” przypisywane są cechy prawie „Zwierzęcej” seksualności (Barczyk, 2010). Inny sposób konstruowania kobiecości cudzoziemek jest pełen fałszywego współczucia wobec ich podrzędnej roli wobec mężczyzn w ich własnych wspólnotach, którego wyrazem jest na przykład wymóg szczelnego zasłaniania ciała w kulturze islamu. To paternalistyczne kolonialne stanowisko trafnie wyraziła w słynnym zdaniu Gayatri Chakravorty Spivak: „Biali mężczyźni ratują brązowe kobiety przed brązowymi mężczyznami” (za A. Loomba, 2011: 166).

\section{Popkultura w narodowej odsłonie}

Popkultura rozważana bywa na kilku płaszczyznach: a) jako uproszczona wersja tak zwanej wysokiej kultury, dostosowana do masowego konsumenta; b) jako nieautentyczna, skomercjalizowana wersja kultury alternatywnej (np. kontrkultury, hip-hopu, feminizmu), wygładzająca jej rewolucyjne treści²; c) jako ta wersja kultury, która unifikuje tożsamości jej konsumentów, zwłaszcza młodzieży (pojęcie tzw. globalnego nastolatka; Melosik, 2013). Ta ostatnia płaszczyzna jest dla potrzeb tego tekstu najistotniejsza.

Zważywszy na znaczenie popkultury dla młodych ludzi, jej nacjonalistyczne odmiany mogą się przyczyniać do podtrzymywania czy wzrostu postaw nacjonalistycznych, co w zasadzie przekreśla założenie o unifikującym, globalnym charakterze popkultury, obecne do niedawna w głównym nurcie refleksji o popkulturze jako zjawisku społecznym (Czubaj, 2005). Jednak może też być tak, że

\footnotetext{
${ }^{1}$ https://pl.wikipedia.org/wiki/Przymusowa_sterylizacja, dostęp 17.03.2017.

${ }^{2}$ Np. E. Illouz pisze, że „feminizm przestał być wyłącznie ruchem politycznym i stał się również kodem kulturowym wykorzystywanym w reklamie, serialach telewizyjnych, filmach i romansach", choć „posługiwanie się kodem kulturowym feminizmu przejawia się często wyłącznie składaniem gołosłownych deklaracji bez poparcia dla jego moralnej siły i politycznych żądań, co wręcz osłabia jego polityczną wyrazistość i zamienia w pusty gest” (Illouz, 2015: 93-94).
} 
treści nacjonalistyczne $\mathrm{w}$ popkulturze są tylko jednym $\mathrm{z}$ wielu przejawów tak zwanego „banalnego nacjonalizmu” - codziennego „wymachiwania narodową flagą”, przyjmowanego i akceptowanego jako oczywisty aspekt życia w obrębie państw narodowych (Edensor, 2005; Billig, 2008). By rozstrzygnąć ten dylemat, trzeba uwzględnić kontekst sytuacyjny i społeczny, ale także długookresowe spojrzenie na popkulturę jako na zjawisko mające swoje centrum i peryferie oraz dominanty i nisze. Na potrzeby tego tekstu odnotuję tylko, iż wielu badaczy i obserwatorów zjawisk popkulturowych w Polsce zwraca uwagę na swego rodzaju „Wzmożenie patriotyczne” rodzimej, polskiej popkultury. Poczynając od mainstreamu, a na niszowych formach gatunkowych kończąc (Czubaj, 2005; Bożek, 2012), mamy od kilku lat do czynienia ze wzrastającym zainteresowaniem tematyką narodową - odwoływaniem się do zdarzeń i bohaterów z dawnej i nowszej historii Polaków i konstruowaniem swego rodzaju popkulturowej mitologii narodowej. Jest to tym bardziej zdumiewające, kiedy weźmie się pod uwagę wcześniejsze okresy młodzieżowej kultury, która np. w latach 60. XX wieku (rock), ale także później (punk) znaczona była tematyką uniwersalnej wolności, równości i antysystemowości, a w latach 90. XX wieku (hip-hop) skoncentrowana była najwyżej na patriotyzmie lokalnym, „ziomalskim” (Zamojska, 2003). Obecnie nasycenie popkulturowych treści nacjonalizmem staje się problematyczne nie tylko ze względu na promowanie nieprzychylnych postaw wobec obcych, lecz także utrwalanie patriarchalnego porządku płci. Ponadto, jak podkreśla Krzysztof Jaskułowski „Kulturą popularną w kontekście badań nad nacjonalizmem warto się zajmować, ponieważ (...) jej szeroki zasięg sprawia, iż ma ona ogromne znaczenie społeczne” (Jaskułowski, 2006: 11).

Eva Illouz twierdzi, że artefakty kulturowe (zwłaszcza te najpopularniejsze) można traktować jako wskaźniki, barometry wartości uznawanych w społeczeństwach i mierzyć nimi zmiany, które się w nich dokonały w skali historycznej (Illouz, 2015: 4). Popkulturę lokalną można też, uwzględniając powyższe założenie, porównywać $\mathrm{z}$ inną lokalną popkulturą, by uzyskać wiedzę o istotnych tendencjach co do dominujących lub uznawanych za dominujące wartości w poszczególnych społeczeństwach. Świetną okazją do analiz tego typu są konkursy piosenki Eurowizji ${ }^{3}$ swoisty przegląd mainstreamowych popkulturowych tendencji w poszczególnych krajach.

${ }^{3}$ Konkurs Piosenki Eurowizji (Eurovision Song Contest (ESC), fr. Concours Eurovision de la Chanson) potocznie Eurowizja, organizowana corocznie od 1956 paneuropejska impreza muzyczna, w której biorą udział przedstawiciele publicznych stacji telewizyjnych zrzeszonych w Europejskiej Unii Nadawców (EBU). http://pl.wikipedia.org/wiki/Konkurs_Piosenki_Eurowizji, dostęp 13.03.2017. 
W Konkursie Piosenki Eurowizji w $2014^{4}$ zwyciężyła piosenka Rise Like a Phoenix (Powstać jak Feniks) w wykonaniu austriackiej drag queen o artystycznym imieniu i nazwisku Conchita Wurst. Polskę reprezentowała piosenka My, Słowianie (wykonywana częściowo po angielsku pod tytułem We are Slavic) - miks rapu i folku z wyraźnymi odniesieniami do instrumentarium (akordeon) i melodyki ludowych przyśpiewek rosyjskich autorstwa producenta hip-hopowego o pseudonimie artystycznym Donatan, wykonana przez wokalistkę o pseudonimie Cleo oraz zespół tancerek i aktorek. Każdy z wymienionych występów odnosił się bezpośrednio do płci (płciowości) i seksualności, choć w bardzo odmienny sposób. Kontekst międzynarodowego konkursu i zaangażowanie widzów z całej Europy i niektórych państw pozaeuropejskich do podejmowania decyzji o zwycięzcy/zwyciężczyni pozwala rozpatrywać to telewizyjne show nie tylko jako wydarzenie czysto estetyczne, lecz jako zjawisko społeczne, a, zważywszy na wypowiedzi czy reakcje instytucjonalnych ciał, na przykład Rosji czy Białorusi, także jako zjawisko polityczne ${ }^{5}$.

Od strony artystycznej zwycięska piosenka/występ sceniczny/performans miała charakter patetycznego popowego festiwalowego hitu, natomiast w połączeniu ze scenicznym wizerunkiem wokalistki oddziaływała na odbiorców w nieoczekiwany, zaskakujący sposób. Conchita Wurst (po polsku dosłownie Muszelka Kiełbasa lub Muszelka w kiełbasie; pseudonim wywołujący asocjacje z organami płciowymi żeńskimi i męskimi), jednych szokowała aż do obrzydzenia, w innych wzbudzała podziw i odczucia absolutnego wyzwolenia. Zamieszanie wokół jej postaci - męskie ciało ubrane w sukienkę, długie włosy i męski zarost twarzy - sprowadzające się $\mathrm{w}$ gruncie rzeczy do niemożliwości natychmiastowego określenia, z kim w sensie płci mamy do czynienia („kobieta z brodą”, „mężczyzna w sukience”, „gej”, „babochłop”), co zwykle robimy bez zastanowienia, intuicyjnie, odsłaniało głęboko zinternalizowaną binarność płci, którą odznacza się nasza kultura. Nieumiejętność poradzenia sobie z identyfikacją, opisem, nazwaniem Conchity Wurst na bardziej ogólnym niż jednostkowy poziomie odsłoniło/odsłania także lukę kulturową, która świadczy o heteronormatywnym rygoryzmie kultury, opresyjnym dla osób nienormatywnych. Nie posiadamy środków językowych, a w każdym razie nie są one w powszechnym użyciu (A.M. Kłonkowska, W. Dynarski, 2016) na określenie osób nienormatywnych płciowo i seksualnie.

4 59. Konkurs Piosenki Eurowizji odbył się 6,8 i 10 maja 2014 r. w Kopenhadze. https:// pl.wikipedia.org/wiki/Konkurs_Piosenki_Eurowizji_2014, dostęp 13.03.2017.

${ }^{5}$ http://eurowizja.org/?p=5491, dostęp 25.03.2017.

${ }^{6}$ Wszystkie określenia pochodzą z komentarzy internautów - http://muzyka.onet.pl/newsy/ eurowizja-2014-polscy-widzowie-ocenili-wystep-conchity-wurst-na-7-punktow-jury-nie/p506w, dostęp: 12.03.2017. 
O ile można występ i zwycięstwo w konkursie Conchity Wurst uznać za demonstrację akceptacji lub otwarcia ze strony Europejczyków na niebinarne rozumienia płci - płci jako kontinuum różnorodnych kombinacji elementów tożsamości, wyglądu i praktyk płciowych i seksualnych - o tyle występ reprezentujący Polskę w tym konkursie można odczytać jako krok w zupełnie odwrotnym kierunku. Polskę reprezentowała piosenka $M y$, Słowianie o treści i formie jakby wyjętych z genderowych analiz dyskursu nacjonalistycznego. Utwór ten jako wizualno-słowno-muzyczna całość ${ }^{7}$ i występ sceniczny ${ }^{8}$ w trakcie konkursu odwoływał się do anachronicznego z punktu widzenia dzisiejszych podziałów politycznych konceptu rywalizacji Słowiańszcyzny z Zachodem, wykorzystując do tego urodę i atrakcyjność seksualną kobiet. Wizualizacją atrakcyjności Słowianek były cielesne oznaki kobiecości - długie nogi, obfite biusty, jędrne pośladki, podkreślane przez skąpe stroje tancerek i wokalistki. Warstwa słowna uwypukla „naturalne”, genetycznie dane piękno i kompetencje w uwodzeniu (My wiemy, jak poruszać tym, co mama w genach dała/ To jest ta goraca krew/ To jest nasz słowiański seks). Ten wyróżniający Słowianki sexapeal (choć to pewnie herezja posługiwać się w tym wypadku obcym wyrazem) w warstwie wizualnej ilustrowały wyzywające ruchy tancerek i układ choreograficzny w trakcie występu scenicznego, którego punktem kulminacyjnym było pochylanie się siedzącej tancerki z szerokim rozstawieniem nóg nad naczyniem przypominającym dzieżę. W wersji wideo widzimy z kolei kobietę w głębokim pochyleniu zamiatającą podłogę (a może klepisko?) w wiejskiej chacie przed starszym mężczyzną w kożuchu zapiętym pod szyję.

Tekst mówi o wyższości Słowianek w tym wyżej sygnalizowanym sensie (Mamy to, czego nie ma nikt inny, Nie ma lepszych od naszych Słowianek) i zwraca się z apelem do obcych mężczyzn (Najlepsze u nas, cokolwiek byś chciał/ Zjeżdżaja do nas $z$ wielu świata stron/ Tu dobra wódka i dobre dziewczyny, Szukaj u nas idealnych żon).

Akcja klipu umieszczona jest na wsi - skansenie, jakby żywcem wyjętej z Chłopów Reymonta w ich filmowej wersji - kryty strzechą dom, podwórko, gdakanie kur w tle. Tancerki i wokalistka występują w stylizowanych strojach ludowych (hafty, bufiaste rękawy, wielowarstwowe spódniczki, fartuszki, kożuchy). To cofnięcie się w czasie w warstwie wizualnej i muzycznej można odczytać jako apoteozę tradycji ludowej, której przechowalnią ma być wieś i wiejski styl życia ( $A$ w teledysku nie ma podtekstów Jak nie wierzysz, to pojedź na wieś). To także apoteoza „swojskości” widzianej z męskiej perspektywy, której wyrazem jest proste wiejskie

\footnotetext{
${ }^{7}$ https://www.youtube.com/watch?v=rr1DSghRqE, dostęp: 12.03.2017.

${ }^{8} \mathrm{https} / /$ /www.youtube.com/watch?v=q8J3GAg5zaI, dostęp: 12.03.2017
} 
jedzenie (chleb, biały ser) i swojska używka - wódka (Wódeczka lepsza niż whisky i giny) i swojskie atrakcyjne kobiety (A nasze panie nie maja kompleksów/ Bo nie maja powodów ich mieć). Kobiety w tej męskiej wizji swojskości są wyłącznie przedmiotem seksualnym oraz wprzęgniętymi w czynności domowe służącymi (zagniatają ciasto, zamiatają podłogę). Mimo że wokalistka w pierwszym zdaniu podkreśla męsko-kobiecą równorzędność autorów klipu (Cleo, Donatan), przechylenie znaczeniowe tekstu i obrazu w stronę tak zwanego "męskiego oka” jest ewidentne i wyłączne. Wykonawczyniami utworu w wersji scenicznej są wyłącznie kobiety. Autor pojawia się tylko w klipie w swojej cywilnej roli i jako jedyny wyposażony jest w atrybuty współczesności (zegarek, komórka, T-shirt, bejsbolówka).

Oficjalne wideo tego utworu opatrzone jest wprowadzeniem, sugerującym jego odczytanie - ma on być ironiczną hiperbolą stereotypu słowiańskiej kobiecości. Jednoznacznie męska perspektywa widoczna i słyszalna w obrazie i tekście sugeruje raczej realizację męskiej fantazji erotycznej. Pominę tutaj niezrozumiały przekaz, dlaczego reprezentantkami Słowianek są wyłącznie kobiety z Polski. Seksistowska pointa (Szukaj u nas idealnych żon) oraz powiązanie etymologiczne angielskiego określenia Słowian (Slavs) z angielskim słowem slaves (niewolnicy) ${ }^{9}$, choć angielski tytuł piosenki został przetłumaczony przez przymiotnik We are slavic, przywołują skojarzenia z targiem niewolnic.

Spośród krytycznych reakcji, które pojawiły się po konkursie, chciałabym wyróżnić parodystyczną przeróbkę tego utworu - tak zwany cover, wyprodukowaną przez lewicowe pismo Krytyka Polityczna ${ }^{10}$. W filmie tym widzimy dziewczynę o jasnych włosach splecionych w warkocz, w stroju ludowym i w koralach, która w scenerii stereotypowego polskiego krajobrazu - łąka, droga polna obsadzona drzewami - śpiewa i tańczy, wykonując uwodzicielskie ruchy ciałem. Wszystko bardzo przypomina oryginał, poza kilkoma elementami - dziewczyna jest niska, głos inny, jej ruchy mniej wystudiowane, sugerujące jednocześnie amatorskie wykonanie i autentyczność przeżywania. W ostatnich ujęciach filmowej opowieści wykonawczyni zdejmuje blond perukę z warkoczem i gorset, odsłaniając krótkie ciemne włosy i gładką, płaską, męską pierś. Istotnym uzupełnieniem przekazu wizualnego jest informacja, iż w roli wokalistki i tancerki wystąpiła Kim Lee, „najpopularniejsza polska drag queen”"11, pochodzący z Wietnamu, mieszkający

\footnotetext{
${ }^{9} \mathrm{https} / /$ www.quora.com/Does-the-word-slave-come-from-the-name-of-the-Slavic-people, dostęp: 12.03.2017.

${ }^{10}$ Kim Lee \& Dżastina Dżary „My, Słowianie“ (cover Krytyki Politycznej, www.youtube.com/ watch?v=zUu-4Ny68PI: dostęp 23..03.2017.

${ }^{11} \mathrm{http}: / /$ kobieta.wp.pl/wywiad-z-kim-lee-najpopularniejsza-polska-drag-queen-598266573 8920577a, dostęp: 23.03.2017.
} 
w Warszawie, polski obywatel Andy Nguyen $^{12}$. Ten krótki filmik jest więcej niż parodią utworu My Słowianie. Poprzez obsadzenie drag queen w roli głównej nawiązuje do zwycięskiego występu Conchity Wurst w Konkursie Eurowizji, ale na głębszym poziomie odsyła także do teoretycznej tezy Judith Butler, która właśnie w występach drag widzi subwersywny akt performatywny podważający naturalność kategorii płci (Butler, 2008). Można tu dostrzec jedną ze strategii podważania heteronormatywności płci, gender bending.

Gender bending to strategia mieszania kulturowych kodów płci, czyli zakłócania klarownego podziału na męskość i kobiecość w warstwie wyglądu i stylów życia. To zaburzanie schematów poznawczych innych osób przez świadome wymykanie się płciowej roli społecznej, przekraczanie jej, niespełnianie oczekiwań genderowych. (...) Gender bending to również czynienie ze swojego ciała i seksualności nieustannego performance’u, a także spontaniczne lub przemyślane przyjmowanie różnych tożsamości” (Zawadzka, 2015: 354)

Z kolei artystyczna strategia subwersji to według Jagody Cierniak „sztuka inteligentnego oporu" (Cierniak, 2012). Subwersja to subtelna manipulacja znaczeniem, która „polega na naśladowaniu, na utożsamianiu się niemalże z przedmiotem krytyki, a następnie delikatnym przesunięciu znaczeń. Ten moment przesunięcia znaczeń nie zawsze jest uchwytny dla widza. To nie jest krytyka wprost, bezpośrednia, tylko krytyka pełna dwuznaczności” (Dziamski 2001: 10). Jednak samo uświadomienie sobie przez odbiorcę możliwości dwuznaczności, wytrąca go z utartych - zwyczajowych - torów myślenia i między innymi umożliwia spojrzenie na znane rzeczy w nowy sposób, tak, by dostrzec nieoczywistość. Cover utworu My, Słowianie z udziałem drag queen skonstruowany jest w taki właśnie sposób. Przez większą część utworu odbiorcy utwierdzani są w przekonaniu pełnej zgodności płci i narodowości z ich przedstawieniem, dopiero ostatnie ujęcie podważa nie tylko pewność aktualnej percepcji, lecz problematyzuje oczywistość ogólnych kategorii - płci i narodu (tożsamości narodowej).

\section{Podsumowanie}

Trzy popkulturowe artefakty próbowałam odczytać z perspektywy konstruktywistycznych konceptów narodu i płci z uwzględnieniem kontekstu edukacyjnego. Interesowało mnie, jaka wspólnota oraz jaka konstrukcja płci i seksualności jest w nich „zakodowana”. Przyjęłam założenie, że rodzaj wspólnoty determinuje

\footnotetext{
12 http://www.homopedia.pl/wiki/Kim_Lee, dostęp: 23.03.2017.
} 
określone konstrukcje płci i seksualności. Im bardziej wspólnota pojmowana jest kolektywistycznie i/lub organicystycznie (jednostka, jej prawa i zakres wolności są pochodną praw i wolności wspólnoty), tym bardziej porządek płci (relacje płci), a także seksualność mężczyzn i kobiet ograniczane są przez ich powinności wobec wspólnoty. Wspólnota, porządek płci i seksualność zastygają w formach traktowanych, postrzeganych i przedstawianych jako naturalne i odwieczne. Ani kształt wspólnoty, ani tym bardziej relacje płci i formy seksualności nie są problematyzowane czy poddawane negocjacji (uważane za negocjowalne). Są przyjmowane jako oczywiste, można powiedzieć, doskonale „przejrzyste”. I odwrotnie - we wspólnotach/zbiorowościach/społeczeństwach „indywidualistycznych”, w których punktem wyjścia dla rozwiązań ustrojowych i społecznych jest jednostka i jej wolności osobiste, także porządek płci i formy seksualności pozostawione są w większym stopniu swobodnej decyzji jednostek, a w każdym razie mogą być problematyzowane, mogą być przedmiotem negocjacji. Te modelowe opisy odnoszą się w pierwszym przypadku - do konstrukcji wspólnoty narodowej w dyskursie nacjonalistycznym, w drugim - do konstrukcji wspólnoty obywatelskiej w dyskursie liberalnym.

We wszystkich analizowanych popkulturowych produkcjach można odnaleźć odniesienia do wspólnoty, choć są to różne wspólnoty. Utwór My, Słowianie zawiera odniesienia do "mitycznej”, tradycyjnej wspólnoty wiejskiej o wyraźnych patriarchalnych cechach w konstrukcji płci i seksualności z wyraźną sugestią, iż prezentowany obraz „historyczny” zasadniczo jest wciąż aktualny. Przywoływana w tekście mityczna Słowiańszczyzna służy podkreśleniu ciągłości pomiędzy tym, co było kiedyś (jak należy domniemywać, u zarania dziejów słowiańskiej etni) i tego, co wciąż rzekomo istnieje - jest niezmienne, naturalne, jest swego rodzaju esencją „naszej” tożsamości przeciwstawianej tożsamości i stylowi życia obcych. Swojskość reprezentują takie elementy jak wiejski styl życia, jedzenie i używki oraz uroda i seksualna potencja kobiet. Redukowanie funkcji kobiet do roli przedmiotu seksualnego ujawnia się przede wszystkim w obraźliwym kojarzeniu słowiańskich/ polskich kobiet z globalnym rynkiem matrymonialnym. Łączenie określonego porządku płci, opartego na jej rygorystycznej binarności oraz dominacji mężczyzn i podporządkowaniu kobiet, z określonym rodzajem tożsamości grupowej/społecznej lub przedstawianie tego porządku płci jako esencjalnej cechy konkretnej wspólnoty z powoływaniem się na jej historyczną ciągłość i wyjątkowość jest, w moim przekonaniu, zbieżne z konstruowaniem narodu i płci w dyskursie nacjonalistycznym. Anachroniczność tego rodzaju konstrukcji ujawnia się w kontekście apelu samych autorów utworu My, Słowianie - by traktować go jako żart. W istocie jednak utwór ten mówi o tym, że warto konserwować tradycyjne wzorce relacji 
płci, ponieważ jest to właściwe (i prawdopodobnie konieczne) ze względu na trwanie określonej grupy i tożsamości grupowej. Dany porządek płci postrzegany jest i aprobowany jako jej sedno/esencja.

Obie pozostałe analizowane kreacje artystyczne zajmują się, na odwrót, dekonstrukcją binarnego rozumienia płci, dekonstrukcją heteronormatywności, obierając strategię gender bending (Zawadzka, 2015: 354). Dopiero konsekwencją takiej dekonstrukcji może być - mogłaby być - konstrukcja wspólnoty, w której nie tylko tożsamość płciowa, ale także tożsamość grupowa nie jest narzuconą z góry formą, do której trzeba się dopasować, lecz jest „do uzgodnienia” (z samym sobą i z innymi). Może mieć też charakter niejednoznaczny, płynny, niepełny bądź wieloraki, może być czymś w rodzaju tak zwanej kreskowanej tożsamości, którą charakteryzują się według Michaela Walzera członkowie społeczeństw imigranckich (Walzer, 1999). Rodzaj wspólnoty (wspólnotowości), tak samo jak płeć i seksualność, pozostają w tym wypadku niedookreślone, otwarte na różnorodność definicji.

Odwołując się do tezy Evy Illouz o artefaktach kultury jako barometrach wartości, chciałabym na koniec odpowiedzieć na pytanie, co nam powyższe analizy mówią o współczesnym młodym pokoleniu oraz pośrednio także o dyskursie edukacyjnym w Polsce.

Muzyczna ekspresja młodego pokolenia od czasów kontrkultury miała wyraźne ideologiczne konotacje, zawierające elementy buntu wobec tradycji, które z czasem stawały się zalążkiem zmiany społecznej (Wertenstein-Żuławski, Pęczak, 1991). Można powiedzieć, iż młodzieńczy bunt rozpatrywany w kategoriach socjologicznych z założenia wnosi nową jakość do dyskusji o urządzeniach społecznych (Zamojska, 1998: 24-30) . Jeżeli potraktujemy utwór My, Słowianie oraz jego pastiszową przeróbkę przez autorów „Krytyki Politycznej” jako wyraz dwóch radykalnie odmiennych dyskursów na temat (pożądanej) wspólnoty własnej oraz płci i seksualności z uwzględnieniem nieproporcjonalności ich popularności ${ }^{13}$, musimy dojść do wniosku, iż współczesne pokolenie młodych Polaków i Polek w swojej większości przywiązane jest raczej do tradycyjnego, nacjonalistycznego $\mathrm{z}$ ducha, obrazu własnej wspólnoty i w konsekwencji także tradycyjnego, binarnego rozumienia płci i nierównościowego porządku płci z dominującą rolą mężczyzn.

Znaczenie powyższego stwierdzenia powinno być rozważane $\mathrm{w}$ kontekście procesów kształtowania tożsamości społecznej młodych ludzi oraz wyróżniających się cech dyskursu edukacyjnego w Polsce po 1989 roku. Dyskurs edukacyjny w okresie transformacji zdominowany został przez idee neoliberalizmu $\mathrm{z}$ akcen-

${ }_{13}$ Proporcja odsłon na internetowym kanale YouTube w przypadku tych dwóch utworów jest nierówna. Oficjalna wersja wideo My, Słowianie ma około 62038107 wyświetleń, natomiast wersja Krytyki Politycznej niecałe 50000 (dane z marca 2017). 
tem kładzionym na rywalizację i indywidualnie budowany sukces szkolny i życiowy (Potulicka, Rutkowiak, 2010). Z drugiej strony, programy i podręczniki szkolne, czyli podstawy szkolnego przekazu międzypokoleniowego, po oczyszczeniu ich z treści PRL-owskich, uznawanych za lewicowe, miały i mają charakter konserwatywny; odwołują się wciąż raczej do romantycznej wizji narodu i państwa niż do wizji wspólnoty obywatelskiej z akcentem na prawa jednostki i poszanowanie praw mniejszości. Dominującą wspólnotą, oferowaną w trakcie szkolnej edukacji uczniom i uczennicom jako platforma tożsamości społecznej, był i jest naród, wspólnota konstruowana ekskluzywnie o cechach patriarchalnego porządku płci (Zamojska, 2010; Popow, 2015; Chmura-Rutkowska, Duda, Mazurek, Sołtysiak-Łuczak, 2016). Wewnętrzne układy szkolne - system klasowo-lekcyjny, hierarchiczny układ władzy z wyróżnioną pozycją nauczyciela względem uczniów, brak realnego wpływu samorządu uczniowskiego na funkcjonowanie szkoły - pozostały w zasadzie niezmienione.

Uwzględniając wyżej wymienione główne cechy socjalizacji młodzieży po 1989 roku, można dojść do paradoksalnego wniosku o jej jednoczesnej skuteczności i nieskuteczności. Identyfikacja młodych ludzi w Polsce z konstrukcją wspólnoty, płci i seksualności o nacjonalistycznym rodowodzie może być przejawem nieskuteczności neoliberalnej presji socjalizacyjnej na młode pokolenie, wyrazem ucieczki przed skrajnie indywidualistycznymi regułami życia społecznego oraz pragnienia budowania tożsamości w oparciu o zastane wzorce wspólnotowe. Z pewnością jest to także wyraz skuteczności oddziaływania edukacji szkolnej, której treści mają w przeważającym stopniu polonocentryczny i patriarchalny charakter.

\section{Literatura}

Acker J. (2009). Przeobrażenia kategorii klasy, rasy i płci. Feministyczne przemyślenia. Tłum.

K. Gawlicz. http://www.ekologiasztuka.pl./pdf/f0077acker.pdf, dostęp: 18.03.2017.

Anderson B. (1997). Wspólnoty wyobrażone. Rozważania o źródłach i rozprzestrzenianiu się nacjonalizmu. Przeł. S. Amsterdamski. Warszawa.

Anthias F., Yuval-Davis N. (2009). Kobiety, naród, państwo. Wprowadzenie. Tłum. A, Czarnacka. http://www.ekologiasztuka.pl/pdf/f0076anthias_davis .pdf, dostęp: 19.03.2017.

Barczyk K. (2010). Afrykańskie przygody Marcina K., prezentera o aksamitnym głosie. http://afryka. org/afryka/afrykanskie-przygody-marcina-k---prezentera-o-aksamitnym-glosie,news/, dostęp: 25.03.2017.

Billig M. (2008). Banalny nacjonalizm. Przeł. M. Sekerdej. Kraków.

Bobako M. (2005). Powrót kobiet do historii. Niedokończony projekt. „Krytyka Polityczna” nr 7/8. 
Bożek J. (2012). Rapem w lemingi, ku chwale Ojczyzny. http://krytykapolityczna.pl/kultura/muzyka/ rapem-w-lemingi-ku-chwale-ojczyzny/, dostęp: 12.01.2017.

Butler J. (2008). Uwikłani w płeć. Feminizm i polityka tożsamości. Przeł. K. Krasuska. Warszawa.

Chmura-Rutkowska I., Duda M., Mazurek M., Sołtysiak-Łuczak A. (2016). Gender w podręcznikach. Projekt badawczy. Raport. T. 1-3. Warszawa.

Cierniak J. (2012). Subwersja czyli sztuka inteligentnego oporu. http://krytyka.org/subwersja-czyli-sztuka-inteligentnego-oporu/, dostęp: 28.03.2017.

Connel R. (2013). Socjologia płci. Płeć w ujęciu globalnym. Tłum. O. Siara. Warszawa.

Czubaj M. (2005). Pop pod flaga biało-czerwona. „Sprawy Narodowościowe. Seria Nowa” nr 27.

Dziamski G. (2001). Wartościq sztuki krytycznej jest to, że wywołuje dyskusje, „Gazeta Malarzy i Poetów" nr 2-3.

Edensor T. (2005). Tożsamość narodowa, kultura popularna i życie codzienne. Tłum. A. Sadza. Kraków.

Gellner E. (1991). Narody i nacjonalizm. Przeł. T. Hołówka. Warszawa.

Graff A. (2008). Rykoszetem. Rzecz o płci, seksualności i narodzie. Warszawa.

Grzebalska W. (2013). Płeć powstania warszawskiego. Warszawa.

Hobsbawn E. (2010). Narody i nacjonalizm po 1780 roku. Program, mit, rzeczywistość. Przeł. J. Macielczyk, M. Starnawski. Warszawa.

Hooks B. (2013). Teoria feministyczna. Od marginesu do centrum. Przel. E. Majewska. Warszawa.

Illouz E. (2015). Hardcorowy romans. Pięćdziesiąt twarzy Greya, bestsellery i społeczeństwo. Przekład J. Konieczny. Warszawa.

Jakubowski W. (2007). Edukacja wobec kultury globalnej, http://www.khg.uni.wroc.pl/files/Microsoft\%20Word\%20-\%20jakubowskit.pdf, dostęp: 1.03.2017.

Jakubowski W. (2014). Media i kultura popularna jako obszar studiów nad edukacją. „Studia Edukacyjne" nr 30.

Janion M. (2006). Niesamowita Stowiańszczyzna. Fantazmaty literatury. Kraków.

Jaskułowski K. (2006). McNacjonalizm, czyli kultura popularna w stużbie narodu. „Kultura Popularna" 3 (17).

Jaskułowski K. (2012). Wspólnota symboliczna. W stronę antropologii nacjonalizmu. Gdańsk.

Kłonkowska A.M., Dynarski W. (2016). Gender i inne kłopotliwe terminy. Czyli jak mówić o różnorodności i (nie)normatywności płciowej i seksualnej? [W:] U. Kluczyńska, W. Dynarski, A.M. Kłonkowska (red.). Poza schematem. Społeczny konstrukt płci i seksualności. Gdańsk.

Koseła K. (2005). Choroba na Polskę. „Tygodnik Powszechny” nr 25, https://www.tygodnikpowszechny.pl/node/125759?language=en, dostęp 28.01.2018.

Loomba A. (2011). Kolonializm/Postkolonializm. Przekład N. Bloch. Poznań.

Macrae C.N., Stangor Ch., Hewston M. (1999). Stereotypy i uprzedzenia. Gdańsk.

Melosik Z. (2013). Kultura popularna i tożsamość młodzieży. W niewoli władzy i wolności. Kraków.

Mouffe Ch. (2008). Polityczność. „Przewodnik Krytyki Politycznej”. Tłum. J. Erbel. Warszawa.

Mouffe Ch. (2015). Demokratyczna polityka musi być stronnicza. http://krytykapolityczna.pl/kraj/ mouffe-demokratyczna-polityka-musi-byc-stronnicza/, dostęp: 10.03.2017.

Mrozik A. (2012). Akuszerki transformacji. Kobiety, literatura i władza w Polsce po 1989 roku. Warszawa.

Popow M. (2015). Kategoria narodu w dyskursie edukacyjnym. Analiza procesów konstruowania tożsamości w podręcznikach szkolnych. Poznań.

Potulicka E., Rutkowiak J. (2010). Neoliberalne uwikłanie edukacji. Kraków. 
Said E.W. (2005). Orientalizm. Przekład M. Wyrwas-Wiśniewska. Poznań.

Scott J.W. (2009). Gender jako pożyteczna kategoria analizy historycznej. Tłum. A. Czarnacka. www. ekologiasztuka.pl/pdf/f0064scott.pdf, dostęp: 19.03.2017.

Spivak G.C. (2011). Czy podporządkowani inni moga przemówić?. Przeł. E. Majewska, „Krytyka Polityczna" 24-25.

Stasiuk K. (2003). Krytyka kultury jako krytyka komunikacji. Pomiędzy działaniem komunikacyjnym, dyskursem a kultura masowa. Wrocław.

Szacki J. (2002). Historia myśli socjologicznej. Wydanie nowe. Warszawa.

Van Dijk T.A. (2001) Badania nad dyskursem. [W:] Van Dijk T.A. (red.). Dyskurs jako struktura i proces. Przeł. G. Grochowski. Warszawa.

Walzer M. (1999). O tolerancji. Przełożył T. Baszniak. Warszawa.

Wertenstein-Żuławski J, Pęczak M. (red.). (1991). Spontaniczna kultura młodzieżowa. Wybrane zjawiska. Wrocław.

Yuval-Davis N. (1997). Gender and Nation. Thousand Oaks.

Zamojska E. (1998). Kulturowa tożsamość młodzieży. Studium empiryczne. Z badań na młodzieża szkół średnich. Poznań-Toruń.

Zamojska E. (2003). Fenomen hip hopu w polskiej kulturze młodzieżowej. [W:] E. Solarczyk-Ambrozik, A. Zduniak (red.). Edukacyjne wyzwania i zagrożenia początku XXI wieku. Warszawa-Poznań.

Zamojska E. (2010). Równość w kontekstach edukacyjnych. Wybrane aspekty równości w polskich i czeskich podręcznikach szkolnych. Poznań.

Zamojski J. (2009). Sterylizacja kobiet romskich w Czechach. [W:] M. Musielak (red.). Wybrane aspekty sterylizacji ludzi ze względów eugenicznych, medycznych i społecznych. Poznań.

Zawadzka A. (2015). Ten pierwszy raz. Konstruowanie heteroseksualności. Warszawa.

\section{Netografia}

https://pl.wikipedia.org/wiki/Przymusowa_sterylizacja, dostęp: 17.03.2017.

http://muzyka.onet.pl/newsy/eurowizja-2014-polscy-widzowie-ocenili-wystep-conchity-wurst-

-na-7-punktow-jury-nie/p506w, dostęp: 12.03.2017.

https://www.quora.com/Does-the-word-slave-come-from-the-name-of-the-Slavic-people, dostęp: 12.03.2017.

http://kobieta.wp.pl/wywiad-z-kim-lee-najpopularniejsza-polska-drag-queen-5982665738920577a, dostęp: 23.03. 2017.

www.youtube.com/watch?v=zUu-4Ny68PI, dostęp: 23..03. 2017.

http://eurowizja.org/?p=5491, dostęp: 20.03. 2017

https://www.youtube.com/watch?v=q8J3GAg5zaI, dostęp: 20.03.2017.

http://www.homopedia.pl/wiki/Kim_Lee, dostęp: 23.03.2017.

https://www.youtube.com/watch?v=rr1DSghRqE, dostęp: 12.03.2017. 